\title{
HISTORICAL AND PHILOSOPHICAL BACKGROUND OF GENETIC ENGINEERING IN THE EU CONTEXTS
}

\author{
Mirela Mezak Matijević, PhD, Assistant Professor \\ Polytechnic of Požega \\ Vukovarska 17, Požega, Croatia \\ mmezakmatijevic@vup.hr
}

\begin{abstract}
Biotechnology as a science has a significant role in society and as such, it significantly changes the status of genetics. Biotechnology can be considered an interdisciplinary science, as it implies modern achievements in chemistry, biochemistry, biology and engineering. There are several types of biotechnology, but it is important to mention the distinction between traditional biotechnology and genetic engineering. Specifically, genetic engineering, as opposed to traditional biotechnology that involves crossing close species, means creating new non-cellular hereditary materials outside the cell and connecting them with a transmitter. With its emergence, biotechnology changes the position of parenting in society, the meaning of life in general and is the subject of numerous discussions in politics, economy, research work etc. However, especially high level of disagreement is in the area of consumer protection. With genetic modification of food, there has been a significant shift in consumer awareness and citizens themselves insist on active participation in the formulation of regulatory rules because the consumption of genetically modified food can negatively affect the health of consumers. In this case, consumers created a network and became active both nationally and supranationally. Despite the various methods of study, the formulation of legal regulations has led to mutual disputes between the EU Member States. Therefore, the central part of the work relates to the jurisprudence of the European Court of Justice in the field of geotechnical engineering. Court judgments and percentages of "obtained" verdicts in favour of the Member States have been analysed.
\end{abstract}

The paper consists of several chapters. In the first chapter, the term of biotechnology, its signifcance for society, and the elemental division of the same are clarified. In the second chapter, in short theses, genetically modified foods and the consumer's position in relation to the same are clarified. Namely, the aim of the paper is to illustrate the consumer's view in order to obtain a complete picture before analysing jurisprudence of the Court of Justice of the European Union. The central part of the paper is devoted to studying jurisprudence of the European Court of Justice in the field of genetic engineering. Namely, the number of disputes regarding the mutual relations between the European Union and the Member States, as well as jurisprudence and the position of the Court of Justice of the European Union have been analysed in regard to favourable regulations.

In the creation of this paper, a number of methods will be used. Above all, the method of analysis will be used for systematic analysis of the problem / phenomenon and this method will try to obtain patterns of behaviour based on scientific knowledge. In contrast, a synthesis method will 
be used to reach a final conclusion. It is also important to mention both the historical method and the descriptive method. Another significant method used will be comparative method and finally teleological method will be used for the purposes of making a conclusion.

Keywords: European Union, Court of Justice of the European Union, Member States, genetic engineering

\section{INTRODUCTION}

Science and technology are growing uncontrollably; at this point their ascending path is unpredictable. Therefore, the purpose of this paper is to present, briefly, the state of biotechnology in society, its potential consequences, and the position of the European Court of Justice and taking a stand in a relatively young discipline. The biotechnology and its divisions are described in the first subsection. Related concepts are also mentioned: eugenics and cloning, based on the scientific assumptions of biotechnology. Different approaches to the concept of biotechnology have been explained. Namely, the aim was to study biotechnology from different aspects in order to gain a complete insight into the positive and negative aspects of this young scientific discipline. A user group that is directly affected by the effects of biotechnology are consumers who consume food produced from genetically modified organisms or foods containing ingredients produced from genetically modified organisms. The last subtitle refers to the practice of the European Court of Justice on genetic engineering. At the end of the introductory part, it is important to note that the work came from the doctoral thesis: Regulatory System of Genetically Modified Organisms in the European Union.

\section{DANGERS OF MODERN BIOTECHNOLOGY}

The simplest definition of biotechnology is as follows: "Biotechnology is the application of biology for human needs". ${ }^{1}$ Every part of human history carries with it the flourishing of certain activities. Thus, biotechnology in natural sciences is what is computing in social sciences. Both disciplines are intertwined in all aspects of today's society. At this point, only one rational question can be asked: Where is the end of the aforementioned activities?

According to the Convention on Biological Diversity, i.e. according to the Confirmation of Convention on Biological Diversity Act, it is stated: "Biotechnology is any technology that uses biological systems, living organisms or parts thereof,

Reiss, M.,J.; Straughan, R., Poboljšati prirodu?, Biblioteka: Scientia, Book 5, Zagreb, 2004, p. 12 
to produce or change products or processes for special purposes." Biotechnology is key in the following disciplines: industry, agriculture, food industry, medicine, environmental protection, conservation of natural resources, etc. As for the division of biotechnology, there are the following types:

1. Red biotechnology is applied in the fields of medicine. It is also considered the most important area of biotechnology since it is usable in drug production and diagnostics. It is believed that red biotechnology is worth approximately $\$ 70$ billion in the USA alone. ${ }^{3}$

2. Green biotechnology or agrobiotechnology is oriented towards the production or development of new genetically modified organisms in order to improve appearance, increase in yield, to build resistance to insects, fungal diseases, viruses and herbicides.

3. White biotechnology refers to the chemical industry, for the purpose of producing environmentally acceptable substances, i.e. the principle of moderation in production and environmental impacts.

4. Grey biotechnology is based on environmental protection, i.e. soil sanitation, waste gas purification, sewage treatment, etc. ${ }^{4}$

In regards to the time of emergence, there are traditional and modern biotechnology. The beginning of traditional biotechnology are found in 10,000 BC, and it was focused on agriculture, the use of microorganisms in the production of beer, wine, bread, yogurt and cheese. Modern biotechnology is divided into genetic engineering, cloning and tissue engineering. "Genetic engineering (or recombinant DNA technology) is the generation of new hybrid hereditary materials outside the cell and their attachment to a transporter (virus, plasmid or other), enabling it to be introduced into a host organism in which they naturally do not exist but in they can be multiply)." "Since recombinant DNA is produced, technology is called recombinant DNA technology or rDNA technology, and the genome-engineered organism is called a genetically modified organism (hereinafter referred to as GMO). In everyday life, GMOs are often mixed with foods derived from genetically modified organisms or animals. Genetic modification involves the transfer

2 Decision on promulgation of the Confirmation of Convention on Biological Diversity Act, Official Gazette, International treaties, 6/96, Article 2

3 Beljo, J.; Herceg, N.; Mandić, A., Biotehnologija i ekologija, Mostariensia, Vol. 19, 2015, pp. 83-92

$4 \quad$ Ibid., pp. 83-92

5 Delić, V., Trideset godina genetičkog inženjerstva: kako je došlo do otkrića mogućnosti rekombiniranja DNA molekula in vitro, Molecular Biology Department, Faculty of Science-Mathematics, Priroda, January 2004, p. 42 
of a part, the whole or a group of genes from DNA of one organism and insertion into DNA of another organism. The fundamental difference between traditional and modern biotechnology is in the affinity of the species that are combined, i.e. in traditional biotechnology, related species are combined, which cannot be said for modern biotechnology. Modern biotechnology creates a new hereditary material that does not exist in the natural environment. ${ }^{6}$ Genetic engineering should get its place on a social ladder. Thus, it is necessary to stop (red light), wait for effects (yellow light) or let it be in all directions - medicinal, dietary, natural etc. ${ }^{7}$

In the introduction the cloning was already mentioned, which is also one of the dangers of modern biotechnology. Clone (Greek - twig) "means a group of individuals or individual organisms, created by asexual propagation, from a sexually acquired unit. Cloning is the process of creating a clone population". ${ }^{8}$ It appeared for the first time in 1962 when British scientist John Gurdon created a frog by transferring nucleus from a frog cell from a frog to another frog's egg nucleus and then he destroyed the nucleus using the UV rays. The first cloned mammal is considered to be a sheep named Dolly where scientists took a cell from adult mammary gland of a sheep and transferred it to another egg cell whose nucleus was previously removed. The first human embryo cloning occurred in 2001 in America. ${ }^{9}$ However, as far as is publicly known, human cloning has not been performed. Since biotechnology has become "an illusive" science, a need arose to define the rules of responsible behaviour that necessarily imply caution and discretion when making a final decision. For example, during reproductive cloning human ineguality is created, i.e. unequal individuals are created, human identity is being infringed upon etc. ${ }^{10}$ Because of the dire need, the term biolaw appeared which constitutes a special branch of law derived from numerous biomedical sciences. Biolaw enabled incorporation of the entire rational legislation, i.e. the prediction of certain situations that have not even happened yet with the aim of creating as high quality national legislation as possible.

It is also necessary to briefly mention the eugenics, a science which is believed to have roots in the far past. This is also mentioned by Plato, who is also considered to have advocated eugenics as a learning that is based on the improvement of the physical and mental qualities of a particular community by influencing

Reiss;Straughan, op. cit., note 1

Lauc, A., Metodologija društvenih znanosti, Sveučilište J.J. Strossmayera u Osijeku, Pravni fakultet, Osijek, 2000., str. 25

8 Reiss;Straughan, op. cit., note 1. p. 43

9 Kešina, I., Etika terapeutskog kloniranja i manipuliranja matičnim stanicama, Crkva u svijetu, Vol. 40, No. 4, 2005, p. 485-505

10 Polšek, D., Sloboda kloniranja, Filozofska istraživanja, Vol. 93, No. 2, 2004, p. 609-620 
conception and birth. "As shepherds and breeders "purify "their herds, so does the legislator must "cleanse" his country." "There are several types of eugenics: old eugenics is divided into positive and negative eugenics. Negative eugenics includes forced abortion, euthanasia, sterilization, etc. Positive eugenics refers to combining parents with pronounced intellectual abilities. The new eugenics also has two types: positive and negative. Positive eugenics strives to trough genetic engineering efforts allow replication of normal genes if spontaneous pathways would cause various diseases, malformations or deaths, while negative eugenics eliminates undesired combinations. ${ }^{12}$

Of the many approaches to biotechnology, theology retains one of the more negative attitudes. The Church protects human life, considers it the greatest good, and the only lord of life is God. However, today human life is not placed on the level of holiness. People turn to the other side and create human life themselves. The fact is that human interventions into human survival have always been present, but there is a clear difference between the Middle Ages and today when euthanasia, abortion or other forms of defining the beginning or end of human life are recognized in national legislations. Eugenics and genetic engineering are completely contrary to the Church's understanding and attitude. ${ }^{13}$ With regard to the philosophical approach, it is considered that a man is never fully shaped. One of the most prominent philosophers in the field of eugenics is Nietzsche who created the concept and character of "superhuman". The process was conceived as a revolution, then evolution, i.e. the aim was the demolition of the world and its rebuilding. Since the effects of biotechnology are both positive and negative, they are also discussed and argued in the field of ethics, and because of the knowledgeable communication, the term bioethics appeared. Bioethics is a discipline that has emerged as a product of the two areas of action: the advancement of technology in biomedicine and the frequent ecological risks that have emerged as a result of human exploitation of nature. Bioethics as a term was first used by an American scientist Rensselaer Potter of the 1970s. As evident, it consists of two terms: bio" which assumes the meaning of biological and ethics that makes up the system of moral values. The following terms refer to bioethics: multidisciplinarity (a set of all activities of crucial importance for bioethics), interdisciplinarity (finding methods for the purpose of co-operation of all activities), transdisciplinarity (overcoming

11 Platon, Država, fifth edition, Beogradski izdavačko-grafički zavod, Beograd, 2002

12 Vuk, M., Eugenika i moderna medicina, Spectrum, Bioetički blok; available at: [file:///C:/Users/Mirela\%20Mezak\%20Matijev/Downloads/Martina_Vuk_Eugenika_i_moderna_medicina\%20(1).pd] Accessed 12.5.2019

13 Matulić, T., Charles Darwin o podrijetlu covjeka: teološko propitivanje metode i argumenata, Bogoslovska smotra, Vol. 78, No. 3, 2008, p. 583-619 
differences between activities), multiperspectivity (cooperation between different fields) and integrativeness. ${ }^{14}$ When it comes to the relationship between a man and technology, there is a need to deal with this relationship, i.e., it needs to be understood that technology are not means that enslave humans, but the means that make human work easier. This process is called demystification of technological development. The second situation of demystification concerns the status of "mother of nature", who has several tasks: to be fertile; suffer numerous pollutions; be self-sufficient and constantly forgiving. The third situation of demystification refers to the progress that needs to be understood both in qualitative and quantitative terms. Man and nature must have a relationship based on a reconciliation basis, and the situation must not move in the direction of war and disorder. In time, the need of special science emerged, and in 1866, the German biologist introduced the term of ecology that studies the relationship between the organism and the environment in which it lives. Of course, the very concept of ecology has evolved, and today it is understood as a set of scientific disciplines that observe the relationship between living beings and the environment. At the end of the last century, ecology has become dominant, and it is assumed that the trend will continue to grow. The goal of ecology, but also of all other sciences, is to achieve a self-regulation ecosystem based on a system that should have the optimal basis regarding input and output elements. I freely dare to point out that the whole world is struggling with the ecological balance, i.e. homeostasis is, at this point, unattainable. In fact, whether it is at all practicable is the question of subjective nature or does everyone have their own perception of ecological or any other balance, and does this makes achieving balance at the global level unattainable? At all times, there whether we consider positive or negative context of any occurrence, balance needs to be taken into account. ${ }^{15}$ Since the negative concept of biotechnology has already been mentioned, a positive concept of biotechnology in medicine should also be mentioned. In its first steps, biology was a descriptive discipline, and the knowledge on regulating and controlling life processes came later. W. Weaver first mentions a new branch of biology, i.e. molecular biology. With the discovery of deoxyribonucleic acid (DNA), basic understanding of life has changed since after that knowledge of hereditary properties and the way in which living beings function has emerged since. The fact is that medicine is not possible without experimentation, but the principle of proportionality should be taken into account at all times. ${ }^{16}$ There are certain principles that should be, realistically, leading in the course of medical interventions and research. The first principle refers to a person

Matulić, T., Bioetika, Glas Koncila, 2001

15 Cifrić, I., Društveni razvoj i ekološka modernizacija, Hrvatsko sociološko društvo, 1998

16 Polšek, D.; Pavelić, K., Društveni značaj genske tehnologije, Institut društvenih znanosti Ivo Pilar, Zagreb, 1999 
and his/her transcendental value in relation to other living beings. The second principle is the principle of the totality or the therapeutic principle advocating the sacrifice of one part of the organism in order to save the whole. This section emphasizes the enormous effect of the principle of proportionality. In layman terms, at certain times, it is justified to perform GMO research for the purpose of obtaining medicines, treatment of certain diseases etc. The last principle is the principle of social solidarity, which means a partial sacrifice for some higher goal, and society cannot ask for an individual's sacrifice greater than he is willing to offer. In this case, it is assumed that there is a written consent. Throughout the years of study, another special discipline emerged - human cytogenetics, which studies the number and form of chromosomes in many human diseases, and the observed numerical and structural chromosome changes may indicate an upcoming disease. ${ }^{17}$ With the development of a technology, other disciplines emerged: pre-implantation diagnosis of hereditary diseases (allows avoiding genetic disorder or disability on the basis of selecting characteristics of an unborn child), in vitro fertilization (a process of fertilization outside the body), molecular genetics (studies gene structure), gene therapy (meaning therapeutic treatment for the purpose of manipulating gene expressions), etc. Soon, new discoveries in medicine began: cell cloning; in 1977 extrauterine fertilization was accomplished, and in 1983 the first child conceived using in vitro fertilization was born; genetic engineering also produced the first drug, Nutritin; also, an important discovery came in 1981 when the $25^{\text {th }}$, so-called, mitochondrial or cytoplasmic chromosome was discovered, the only chromosome located outside the cell nucleus. ${ }^{18}$ In 1990, the four-year-old girl Ashanti de Silva became the first human treated with genes. The girl was suffering from ADA deficiency and mostly stayed isolated in her house because she was subject to various diseases. The doctors took a blood sample, "purified" the white blood cells and mixed them with the virus containing the ADA gene. After that, the white blood cells containing the ADA genome were reintroduced to the girl's body and thus enabled the functioning of the immune system.

\section{EUROPEAN JURISPRUDENCE IN GENETIC ENGINEERING CASES}

According to Maslow's hierarchy, food needs are at the bottom of the pyramid along with other existential needs. All needs have to be maintained at the optimum level, at the homeostasis level, but there is a huge difference between consumers. Consumers at any level, cannot be understood in a homogeneous sense because

\footnotetext{
17 Paediatrician Lejeune found in 1958 numerical chromosomopathy for Down syndrome

18 It is inherited exclusively from the mother since her egg keeps cytoplasm during fertilization
} 
they differ in behaviour, attitudes, values, beliefs, age, gender, education level, and income. Likewise, perceptions about the importance of food are different so there are two different schools on food quality. One of them is a school based on a holistic approach, i.e. it equates quality with all the desirable properties the product needs to have. ${ }^{19}$ As the theory of self-organization has already been explained, it can be freely applied in the previous case. Hence, the holistic approach advocates autonomous shaping of each human's health. It is based on sustainability, flexibility and networking settings. On the other hand, there is a principle of excellence that "suggests that products may have desirable characteristics that the consumer cannot, using their palate, experience as a part of quality". ${ }^{20}$ It is evident that the holistic approach is one that is protective in terms of consumer protection policy.

According to the European Consumer Protection Strategy, the following objectives are foreseen:

1. Promoting consumer safety through enhanced product identification and traceability, increased food safety measures, etc.

2. Better knowledge of consumer rights through various tools, for example Consumer Classroom that has the purpose of educating consumers to better understand the market;

3. Better implementation of consumer protection regulations by introducing simple and speedy court procedures, cross-border actions against violations of the EU regulations, etc.

4. Grouping consumer interests according to sectors, for example energy, traffic, food, etc.

5. Strengthening the role of consumers by providing choices, better information, awareness of rights and legal protection. ${ }^{21}$

In the 1990s, when GM corn was put on the market, consumer concerns about food products increased. Likewise, there has been a series of affairs in Europe, so consumers have become active through various associations, they have worked on raising awareness, they have initiated court proceedings, etc.

19 Grunert, K., Food quality and safety: consumer perception and demand, European Review of Agricultural Economics, Vol. 32, No. 3, 2005, pp. 369-391, 372

$20 \quad$ Ibid., p. 372

21 According to [https://ec.europa.eu/info/policies/consumers/consumer-protection/consumer-strategy_hr] Accessed 05.02.2019 
The starting point of consumer protection is the precautionary principle that consists of the following elements: scientific insecurity, risk assessment and risk management. The principle advocates action in scientific disagreement situations, i.e. in the case of lack of scientific evidence of the negative impact of food on human health and the environment. Measures taken in such circumstances must be proportionate and the trade restriction must be consistent and proportionate to the limitations. In such situations, when a precautionary principle requires action, a moratorium or a ban on certain products or technological processes may be required. Risk Assessment must be based on scientific evidence that must be taken into account in an independent, objective and transparent manner. Risk management is a system in which, the most appropriate political action is chosen among many available actions, and that is the action that includes the results of the risk assessment with scientific data and the social, economic and political interests. The following paragraphs will cover the case law on genetic engineering and analyse the relationship of precautionary principle for consumer protection and European jurisprudence.

Judicial proceedings in genetic engineering cases do not have a long history since food scandals appeared only at the beginning of the 1990s. Court ${ }^{22}$ of the European Union (Court of Justice of the European Union) has the following judicial instances: the Court (European Court) ${ }^{23}$ which is competent to resolve the claims on the previous decisions of the national courts, annulment proceedings and appeals and the General Court, which is competent in the proceedings of annulment brought by individuals, companies and governments of individual Member States. Certain changes have been introduced in the European court practice after the Lisbon Treaty. Among other things, the Charter of Fundamental Human Rights became legally binding and thus affected certain rights: for example "ban on making the human body and its parts as such a source of financial gain" 24 , "ban on reproductive cloning human beings". ${ }^{25}$ The Charter's application is limited and difficult because it does not apply to the regulations of Poland and the United Kingdom. ${ }^{26}$ In the procedural sense, certain changes have also been made: active

22 There is a controversy over the translation and use of the term "justice" in Court's name. For example, the term is used in the English, French, Italian system, while for example Germans remove that term from the official name

23 In Article 19 of the UEU only the word "Court" is used, while the adjective European has been defined through practice

24 Charter of Fundamental Human Rights of the European Union, Official Journal of the European Communities, 2000 / C 364/01, Art. 3 (2) C

$25 \quad$ Ibid., Art. 3(2)d

26 Protocol on the application of the Charter of Fundamental Rights of the European Union to Poland and the United Kingdom, Official Journal of the European Communities C 202 (2016) 
legitimacy is also extended when it comes to the individual as the applicant ${ }^{27}$ and also to the Committee of the Regions ${ }^{28}$ and in an indirect manner to national parliaments. ${ }^{29}$ In addition to the changes above, the Court has been empowered to control the validity and interpretation of acts of agencies, bodies and offices. The novelty in the system is the introduction of an emergency pre-trial procedure, when a request is made by a national court before which proceedings are in progress for a person in custody.

The analysis of judgements of the Court of Justice was done chronologically. Judgment of 5 October 2005 of the First Instance Court (Fourth Chamber) was on a dispute between Oberösterreich Estate and the Republic of Austria and the Commission of the European Communities on harmonization of laws and national provisions on the derogation from the harmonization measures, the ban on the use of genetically modified organisms in Upper Austria and the conditions for application of Article 95(5) of the Treaty establishing the European Community ${ }^{30}$ reads as follows: "after the adoption by the Council or by the Commission of a harmonisation measure, a Member State deems it necessary to introduce national provisions based on new scientific evidence relating to the protection of the environment or the working environment on grounds of a problem specific to that Member State arising after the adoption of the harmonisation measure, it shall notify the Commission of

27 Article 230 of the EU Treaty, and in terms of procedural legitimacy of individuals read: “ Any natural or legal person may, under the same conditions, institute proceedings against a decision addressed to that person or against a decision which, although in the form of a regulation or a decision addressed to another person, is of direct and individual concern to the former." However, Article 263/4 of the Treaty on the Functioning of the European Union has changed the status of the applicant and reads: "Any natural or legal person may, under the conditions laid down in the first and second paragraphs, institute proceedings against an act addressed to that person or which is of direct and individual concern to them, and against a regulatory act which is of direct concern to them and does not entail implementing measures." There are differences in the above-mentioned settings (for example deleting certain terms, defining a regulatory act, implementing measures etc.) and the meaning itself depends on the interpretation of the EU Court

28 Pursuant to Article 263/3 of the Treaty on the Functioning of the European Union "the Court shall have jurisdiction under the same conditions in actions brought by the Court of Auditors, by the European Central Bank and by the Committee of the Regions for the purpose of protecting their prerogatives." In addition, Article 8 (2) of the Protocol on the Application of the Principles of Subsidiarity and Proportionality clearly states the following: “... he Committee of the Regions may also bring such actions against European legislative acts for the adoption of which the Constitution provides that it be consulted."

29 Except for the changes envisaged in the Lisbon Treaty, Protocol no. 2 on the application of the principle of subsidiarity and proportionality in Article 8 (1), which provides that: "The Court of Justice of the European Union shall have jurisdiction in actions on grounds of infringement of the principle of subsidiarity by a European legislative as adopted pursuant to Article 263 of the Treaty on the Functioning of the European Union by Member States, or notified by them in accordance with their legal order on behalf of their national Parliament or a chamber of it."

30 Merged cases T-366/03 and T-235/04, Oberösterreich Estate and Republic of Austria v. Commission of the European Communities [2005] ECR II-04005; ECLI:EU:T:2005:347 
the envisaged provisions as well as the grounds for introducing them. ${ }^{\prime 31}$ In November 2003, the Republic of Austria and the Oberösterreich Estate filed a lawsuit against the European Commission. The subject of the dispute referred to deviation from Guideline 2001/18 or Article 95(5) on the derogation from national legislation due to the specificity of the Member State. After the procedure was conducted, the Court ruled in favour of the European Commission and ordered the applicants to pay court costs. In the appeal (Joined Cases C-439/05 P and C-454/05 P), the Republic of Austria and the Oberösterreich Estate sought to annul the judgment in joined cases T-366/03 and T-235/04. ${ }^{32}$ However, on 13 September 2007, a verdict was also issued, also with a negative outcome for the Republic of Austria. In the described court proceedings, despite the principle of subsidiarity and the promotion of national legislation, the precautionary principle has prevailed in the legal process.

The following is Case C-165/08 between the Commission of the European Communities and the Republic of Poland of 16 July $2009^{33}$ where a Member State has failed to fulfil its obligations, i.e. has breached Articles 22 and 23 of the Guidelines 2001/18 $8^{34}$ and Articles 4(4) and 16 of the Guideline 2002/53/EC of 13 June on a common catalogue of varieties of agricultural plants. ${ }^{35}$ The Republic of Poland is obliged to pay for its own and 2/3 of the Commission's expenses. The remaining $1 / 3$ of the cost is at the expense of the Commission because the Commission has partially succeeded. Namely, the Republic of Poland has called upon on the circumstances within their state borders. The population is largely devoted to Christian values, as are the members of Parliament themselves. In addition, the political parties, represented by the majority in the parliament, have advocated those values in their programs. The Republic of Poland departs from stereotypes in the field of genetic engineering in Europe. Specific national interest has prevailed over supranational uniformity.

31 Consolidated version of the Treaty establishing the European Community, Official Journal C 325, December 242002

32 Court judgement (Third Chamber) of September 13 2007, Oberösterreich Estate and the Republic of Austria against Commission of the European Community. Joined cases C-439/05 P and C-454/05 P; ECLI: ECLI:EU:C:2007:510

33 Case C-165/08 Commission of the European Communities v. Republic of Poland [2009]; ECLI: ECLI:EU:C:2009:473

34 Article 22 refers to Member States that, by fulfilling the criteria set out in the Guidelines, may prohibit, restrict or impede the placing of GMOs on the market either on their own or as a part of the product. The second article refers to safeguard clauses

35 Article 4(4) lays down all the necessary measures when introducing GMOs into the environment to avoid affecting human health and the environment. Article 16 prescribes the conditions under which certain Member States may prohibit the use of genetically modified varieties 
The next case is T-139/07 $7^{36}$ concerning the proceedings before the First Instance Court between "Pioneer Hi-Bred International" and the Commission of 4 September 2009 on the harmonization of laws in the deliberate introduction of genetically modified organisms into the environment. The applicant is "Pioneer Hi-Bred International" and the defendant is the Commission of the European Communities. The Commission has not fulfilled its obligations under Article 18(1) of Directive 2001/18/EC. ${ }^{37}$ Since an oversight occurred, there was no necessity of court proceedings and the Commission shall reimburse its costs and expenses of the applicant. Case T-139/07 is purely technical in nature because the lawsuit was filed due to a failure to fulfil obligations. Since the European Commission has in the meantime committed its obligations, the lawsuit lost its purpose and there was no need for a verdict to be issued. Thereafter, a series of correspondence between the applicants, the Court and the European Commission followed regarding the amount of court fees, so it is unnecessary to analyse numerous notices that are not the subject of this paper.

Judgment of the Court (Grand Chamber) of 6 September $2011^{38}$ referring to Regulation (EC) No. 1829/2003 (Articles 2 to 4 and Article 12) ${ }^{39}$, Guideline 2001/18/EC (Article 2) ${ }^{40}$, Guideline 2000/13/EC (Article 6) ${ }^{41}$ and Regulation (EC) No. 178/2002 (Article 2) ${ }^{42}$. The judgement refers to the presence of pollen from GM plants and the consequences when placing the product on the market, the definition of "organism" and "food for human consumption containing ingredients produced from genetically modified organisms". According to Article 2.5 of Regulation (EC) 1829/2003 the definition of GMOs does not include pollen from different GM maize which has lost its reproductive capacity and is completely incapable of transferring the genetic material it contains. In accordance with Articles 2.1, 2.10 and 2.13 and Article 3(1)(c) of Regulation 1829/2003, Article 2 of Regulation 178/2002, Article 6(4)(a) Guideline 2000/13/EC under GMO does not consider the substance as a pollen containing genetically modified DNA or genetically modified protein; products such as honey or food additives containing such substances as "food ... containing ingredients produced from [genetically modified organisms]". Finally, Articles 3(1) and 4(2) of Regulation 1829/2003

\footnotetext{
36 Case T-139/07 Pioneer Hi-Bred International v. Commission; ECLI: EU: T: 2009: 307

37 This article refers to the procedure of publication of the decision and the content thereof

38 Case C-442/09 Karl Heinz Bablok and Others v. Freistaat Bayern [2011] ECR Page 00000;ECLI:EU:C:2001:541

39 Articles 2-4 refer to the definition of terms, scope and requirements of the Regulation, and Article 12 on labelling procedures

40 Definitions of terms that are characteristic of this Guideline

41 Article 6 deals with the concept of ingredient, labelling, presentation of the same etc.

42 Article 2 defines the term food
} 
imply an obligation to approve and supervise food and the tolerance threshold for labelling provided for in Article 12(2) of the same Regulation cannot be applied analogously to the preceding articles. In this case, the Court did not recognize the pollen emanating from GM maize as a GMO, and it has lost the ability of transferring genetic material.

In Case C-313/11 $1^{43}$ it was ruled in favour of the Republic of Poland, and the case was complaint of the European Commission's that Poland failed to fulfil its obligations under Regulation (EC) 1829/2003. Thus, the Republic of Poland has adopted an act prohibiting the production, placing on the market and the use in animal feed of genetically modified animal feed as well as GMOs intended for use in animal feed. With the subsequent extension of the entry into force of the above-mentioned Act, the Republic of Poland notified the European Commission, and the Commission sent back a letter citing a violation of Regulation $1829 / 2003$ because the whole procedure ultimately affects market placement, free circulation, movement and use of animal feed already approved on the basis of that Regulation. The Republic of Poland has emphasized the fact that the prohibition has not yet came into force at the time of the judgement, thus the suit was rejected and the European Commission was obliged to compensate for the costs of the proceedings. The Court considered that the European Commission did not submit enough elements to prove the violation of the principles of legal certainty and has ruled in favour of the Republic of Poland.

The judgment of the General Court (Ninth Chamber) of 13 December 2013 was made on the dispute between Hungary and the Commission (T-240/10). ${ }^{44}$ It was based on the annulment of the Commission's Decision 2010/135/EU on placing genetically modified potatoes on the market. The European Commission was obliged to compensate for the costs of the proceedings in this case. The whole case was based on the precautionary principle, i.e. possible release into the environment or placing on the market of GMOs only if there is scientific certainty in the actual release of genetically modified potatoes.

In a case of 2 October 2014 (Case C-478/13) - European Commission v Republic of Poland (Infringement of a Member State's obligation - Directive 2001/18/ EC - Intentional introduction of genetically modified organisms (GMOs)into the environment - Placing on the market - Article 31, paragraph 3, item (b) - Location of GMO crops - Obligation to notify competent authorities - Obligation to es-

\footnotetext{
43 Case C-313/11 Infringement of a Member State's obligation - Regulation (EC) 1829/2003 - Animal feed - Genetically modified food - Production, placing on the market or use - National ban which has not yet entered into force; ECLI: EU: C: 2013: 481

44 Case T-240/10 - Hungary v. Commission - of 13 December 2013; ECLI: EU: T: 2013: 645
} 
tablish a public register - Loyal co-operation), the Republic of Poland was obliged to reimburse the costs because it failed to inform the local authorities regarding the deliberate introduction of GMOs into the environment, did not publish the locations publicly. ${ }^{45}$

The next item according to the chronology is the General Court Resolution of 16 September 2014 (Case T-405/10) concerning the annulment of Commission's Decision 2010/135/EU on placing genetically modified potatoes on the market. ${ }^{46}$

TestBioTech eV, European Network of Scientists for Social and Environmental Responsibility eV, Sambucus eV lodged an appeal on 14 February 2017 (Case T-177/13) against the Verdict of the General Court (Fifth Chamber) of 15 December 2016 (Case C-82/17 P47). TestBioTech eV, European Network of Scientists for Social and Environmental Responsibility eV, Sambucus eV appealed to the abolition of the judgment delivered on 19 December 2016. Finally, it was decided that the complaints were not based on Decision 2012/347 granting Monsanto approval for placing genetically modified soybeans on the market and the European Commission had to be compensated for court costs.

Judgment of the Court of 13 September 2017 in Case C-111/16 concerns the request for a preliminary ruling - Agriculture - Genetically modified food and feed Emergency measures - National measure prohibiting the cultivation of genetically modified maize MON 810 - Retention or extension measures - Regulation (EC) No. 1829/2003 - Article 34 - Regulation (EC) No. 178/2002 - Articles 53 and 54 - Conditions of application - The precautionary principle concerns the Member States which should adopt a provisional measure, until the European Commission decides not to define the status of the product so as to not affect the safety of people, animals or the environment. The request referred to the group of manufacturers of genetically modified maize MON 810 whose production is in contradiction with national legislation. According to Article 34 of Regulation (EC) No 1829/2003, if approved products present a serious risk to human, animal or environmental health, and where there is a need to suspend or amend the author-

45 Judgment of the Court (Ninth Chamber) of 2 October 2014 - European Commission v Republic of Poland (Infringement of a Member State's obligation - Directive 2001/18 / EC - Intentional introduction into the environment of genetically modified organisms (GMOs) - Placing on the market - Article 31 st bullet point 3 (b) - Location of GMO crops - Obligation to notify competent authorities - Obligation to establish a public register - Loan co-operation); ECLI: EU: C: 2014: 2253

46 Case T-405/10: Judgment of the General Court of 16 September 2014 - Justice \& Environment v Commission (Harmonization of legislation - Intentional introduction of GMOs into the environment - Procedure for marketing authorization - Internal review request - Annulment Challenged or Relevant Decisions - Termination of Disputes - Suspension of Proceedings); ECLI: EU: T: 2014: 821

47 Case: TestBioTech and Others v Commission C 82/17 P; ECLI:EU:T:2016:736 
ization, it is necessary to act in accordance with Articles 53 and 54 of Regulation $178 / 2002$. These articles provide emergency measures in serious risk situations. As to the first question, should the European Commission adopt urgent measures, the Court found that the Commission was not required to impose emergency measures (Article 34 of Regulation 1829/2003 in conjunction with Article 53 of Regulation 178/2002) in a situation where the product poses a serious risk to human, animal or environmental health. The second and fourth questions referred to Articles 34 of Regulation 1829/2003 in conjunction with Article 54 of Regulation $178 / 2002$, i.e. whether a Member State should take urgent measures at national level until the Commission decides on their extension, modification or termination. The Court's view was that a Member State could take urgent measures at the national level. The third question referred to the precautionary principle, i.e. Member States are not allowed to, pursuant to Article 54 of Regulation 178/2002, adopt provisional emergency measures based solely on that principle without fulfilling material conditions laid down in Article 34 of Regulation 1829/2003 (on emergency measures taken if the product presents a serious risk to human, animal or environmental health).

Case C-528/16 of 25 July 2018 refers to the following: Request for a preliminary ruling - Intentional introduction of genetically modified organisms into the environment - Mutagenesis - Directive 2001/18/EC - Articles 2 and 3 - Annexes IA and IB - Genetically Modified Organisms - Methods of genetic modification which are conventionally used and considered safe - New techniques/methods of mutagenesis - Risks for human health and the environment - Margin of Member States' judgment when transposing the Directive - Directive 2002/53/EC Common catalogue of varieties of agricultural plant species - Herbicide resistant herbal varieties - Article 4 - Acceptability for a common catalogue of genetically modified grains obtained by mutagenesis - Requirement in the field of human and environmental health protection - Exemption. GMOs, whether introduced for experimental purposes or as commercial products, may cross borders trough their reproduction. Guidelines 2001/18 has been drafted on the basis of precautionary principle and its provision should be interpreted in accordance with the said principle. The main point is that it has been agreed that organisms obtained by mutagenesis techniques / methods and not used conventionally enter into the scope of Guidelines 2001/18. Similarly, organisms obtained using conventional mutagenesis methods and are used conventionally and have a proven long-term safety are not subject to the same Guidelines. 


\section{CONCLUSION AND RECOMMENDATIONS}

The problem of legal definition and managing of GMOs is as global as national. Member States can hardly co-ordinate on a supranational level and adopt a legal regulation that would regulate the GMO approval procedure. Hence, supra-national legislation is set on a unified basis, taking into account the specificities of individual Member States. In addition, consumer protection is an important part of the legal system, especially in sensitive cases such as genetic engineering. An extreme example is Poland (Case C-165/08) appealing to religious commitment of the majority of its citizens and expressing a different interpretation of certain legal provisions in view of the Church's stand on GMOs and biotechnology is clear. In Cases C-165/08 and C-111/16, there was a particular emphasis on advocacy of the principle of subsidiarity. In other words, national interests and the religious environment were a trigger for implementing the principle of subsidiarity. Proof of this are numerous court proceedings, which, in their judgements in most cases call for temporary measures to be taken by the Member States and regulate the GMO approval process, until the European Commission makes the final decision. Conditional, the conflict between the two principles, the principles of subsidiarity and the precautionary principle will always be present in genetic engineering. $\mathrm{Al}$ though the precautionary principle is being implemented by the European Union and the Member States, in certain cases (for example Case T-240/10, C-528/16) it is necessary, for the purposes of protecting human and animal health and the environment, to define uniform rules in order to protect Member States, especially neighbouring states, against reproduction of unwanted products. Namely, the fact is that controversy of this nature will always exist because it is impossible for such a sensitive area to be thoroughly legally regulated in such a complex community. The purpose of regulating GMOs should be to protect the European Union at a supra-national level, and ensure the functioning of legal regulations at national level to Member States through certain provisional measures, until the European Commission confirms or denies the same decision.

\section{REFERENCES}

\section{BOOKS AND ARTICLES}

1. Abels, G., The Long and Winding Road from Asilomar to Brussels: Science, Politics and the Public in Biotechnology Regulation, Science as Culture, Vol. 14, No. 4, 2005, p. 339-353

2. Alagić, D., M.; Smajlković, F.; Čaklovica, Genetski modificirani organizmi (GMO) u prehrani ljudi, MESO, Vol. 7, no. 5, 2005

3. Arvanitoyannis, I.S., the Politics and Science Behind GMO Acceptance, Critical Reviews in Food Science and Nutrition, Taylor and Francis Group, 2007 
4. Beljo, J.; Herceg, N.; Mandić, A., Biotehnologija i ekologija, Mostariensia, Vol. 19, No. 1, 2015

5. Burnside, A.S., Sveti Augustin o nastanku ljudskog života, Obnov. Život, Vol. 57, No. 2, 2002, p. 197-205

6. Carson, L., Lee, R., Consumer Sovereignty and the regulatory History oft he European Market for Genetically Modified Foods, Environmental Law Review Vol. 7, 2005, p. 173-189

7. Cifrić, I., Čovjekova okolina kao problem kulture, Pravni vjesnik, Vol. 5, No. 1-2, 1989, p. 23-32

8. Cifrić, I., Društveni razvoj i ekološka modernizacija, Hrvatsko sociološko društvo, 1998

9. Cifrić, I., Trgovina životom, Soc. ekol. Zagreb, Vol. 7, No. 3, 1998, p. 271-290

10. Čorak, H., Koristi i rizici genskog inženjerstva, Soc ekol. Zagreb, Vol. 8, No. 4, 1999, p. 335-352

11. Ćapeta,T.; Rodin, S., Osnove prava Europske unije na temelju Lisabonskog ugovora, II. izmijenjeno i dopunjeno izdanje, Narodne novine, d.d., Zagreb, lipanj, 2011

12. D'Agostino, F., Bioetika kao pravni problem, Vladavina prava, Zagreb, Vol. 4, No. 5, 2000

13. Delić, V., Trideset godina genetičkog inženjerstva: kako je došlo do otkrića mogućnosti rekombiniranja DNA molekula in vitro, Zavod za molekularnu biologiju, Prirodoslovnomatematički fakultet, Priroda, 2004

14. Ferretti, M. P., Lay Public or Experts? e-Participation in Authorization for GMO Products int he European Union, Review of Policy Research, Vol. 25, No. 6, 2008

15. Gowrishankar, J., Regulation of genetically modified organisms: has the time come to amend the law?, Current Science, Vol. 96, No. 12, 2009

16. G. Grunert, K., Food quality and safety: consumer perception and demand, European Review of Agricultural Economics Vol. 32, No. 3, 2005, pp. 369-391

17. Hrabar, D., Planiranje obitelji - od pobačaja do zdravstvene edukacije, Izvorni znanstveni članak, Revija za socijalnu politiku, Vol. 5, No. 1, 1998

18. Hrvatska biskupska konferencija, Nacionalni Katehetski ured, Plan i program katoličkoga vjeronauka za četverogodišnje srednje škole, Ministarstvo znanosti, obrazovanja i športa, Zagreb, 2009

19. Jones, S.; Van Loon, B., Genetika za početnike, Naklada Jesenski i Turk, Zagreb, 2002

20. Jošt, M., Od otkrića nepoznatog do iskorištavanja nesigurnog, Kana, XXXVIII(6/411), 2007, p. 36-38

21. Kešina, I., Genetika i genetičko inženjerstvo - povijest, šanse i opasnosti, Crkva u svijetu, Vol. 35, No. 1, 2000

22. Kešina, I., Etika terapeutskog kloniranja i manipuliranja matičnim stanicama, Crkva u svijetu, Vol. 40, No. 4, 2005, p. 485-505

23. Lauc, A., Metodologija društvenih znanosti, Sveučilište J.J. Strossmayera u Osijeku, Pravni fakultet, Osijek, 2000

24. Matulić, T., Bioetika, Glas Koncila, 2001

25. Matulić, T., Charles Darwin o podrijetlu čovjeka, teološko propitivanje metode i argumenata, Izvorni znanstven rad, Bogoslovska smotra, Vol. 78, No. 3, 2008, p. 583-619 
26. Matulić, T., Život u ljudskim rukama, Glas Koncila, 2006

27. Platon, Država, Filozofska biblioteka, Zagreb, 2001

28. Platon, Pa,rmenid, Filozofska biblioteka Dimitrija Savića, Zagreb, 2002

29. Polšek, D., Pavelić, K., Društveni značaj genske tehnologije, Institut društvenih znanosti Ivo Pilar, Zagreb, 1999

30. Polšek, D., Sloboda kloniranja, Filozofska istraživanja, Vol. 93, No. 2, 2004, p. 609-620

31. Reiss, M.,J.; Straughan, R., Poboljšati prirodu?, Biblioteka: Scientia, Knjiga 5, Zagreb, 2004

32. Smith, J., M., Sjeme obmane, Razotkrivanje korporacijskih i vladinih laži o sigurnosti GENETSKI MODIFICIRANE HRANE koju jedete, Biovega, Zagreb, 2005

33. Tiberghien, Y., Competitive Governance and the Quest for Legitimacy in the EU: the Battle over the Regulation of GMOs since the mid-1990s, European Integration, Vol. 31, No. 3, 2009, p. 389-407

34. Yount, L., Genetika i genetičko inženjerstvo, Biblioteka Vidici, 1997

35. Verma, A.S. et al., Biotechnology in the Realm of History Journal List, J Pharm Bioallied Sci, Vol.3, No. 32011

\section{EU LAW}

1. Treaty on European Union, Official Journal of the European Union C $321 \mathrm{E} / 5$

2. Consolidated version of the Treaty on European Union and Treaty on the Functioning of the European Union, Official Journal of the European Union, C 83/01, 7.06.2016

3. EU Charter of Fundamental Rights, Official Journal of the European Union 2000/C 364/01

4. Protocol on the Application of the Charter of Fundamental Rights of the European Union to Poland and to the United Kingdom, Official Journal of the European Union C 202 (2016)

5. Regulation (EC) No. 178/2002 of the European Parliament and Council of January 28 laying down the general principles and requirements of food law, establishing the European Food Safety Authority and laying down procedures in matters of food safety, Official Journal of the European Union, L 31/1, 1.2.2002

6. Regulation (EC) No 1829/2003 of the European Parliament and of the Council of 22 September 2003 on genetically modified food and feed , Official Journal of the European Union L, 18.10.2003.

7. Regulation (EC) No 1830/2003 of the European Parliament and of the Council of 22 September 2003 concerning the traceability and labelling of genetically modified organisms and the traceability of food and feed products produced from genetically modified organisms and amending Directive 2001/18/EC, Official Journal of the European Union L 268, 18.10.2003., p. 24-28

8. Guideline 2001/18/EC of the European Parliament and of the Council of 12 March 2001 on the deliberate release into the environment of genetically modified organisms and repealing Council Directive 90/220/EEC, Official Journal of the European Union L 106, 17.4.2001., p. 1-39 


\section{LIST OF NATIONAL REGULATIONS}

1. Decision on promulgation of the Confirmation of Convention on Biological Diversity Act, Official Gazette, International treaties, 6/96, 6/96

2. Confirmation of Convention on Biological Diversity Act (Cartagena Protocol) with Convention on Biological Diversity, Official Gazette, International treaties, 7/02

3. Genetically Modified Organisms Act, Official Gazette (70/05, 137/09, 28/13, 47/14, $15 / 18,115 / 18)$

\section{COURT OF JUSTICE OF THE EUROPEAN UNION}

1. Case C-165/08 Commission of the European Communities v. Republic of Poland [2009]; ECLI: ECLI:EU:C:2009:473

2. Case C-442/09 Karl Heinz Bablok and Others v. Freistaat Bayern [2011] ECR Page 00000;ECLI:EU:C:2001:541

3. Case C-313/11 Infringement of a Member State's obligation - Regulation (EC) 1829/2003 - Animal feed - Genetically modified food - Production, placing on the market or use - National ban which has not yet entered into force; ECLI: EU: C: 2013: 481

4. Judgment of the Court (Ninth Chamber) of 2 October 2014 - European Commission v Republic of Poland (Infringement of a Member State's obligation - Directive 2001/18 / EC - Intentional introduction into the environment of genetically modified organisms (GMOs) - Placing on the market - Article 31st bullet point 3 (b) - Location of GMO crops - Obligation to notify competent authorities - Obligation to establish a public register - Loan co-operation); ECLI: EU: C: 2014: 2253

5. Court judgement (Third Chamber) of September 13 2007, Oberösterreich Estate and the Republic of Austria against Commission of the European Community. Joined cases C-439/05 P and C-454/05 P; ECLI: ECLI:EU:C:2007:510

6. Case: TestBioTech and Others v Commission C 82/17 P; ECLI:EU:T:2016:736;

7. Case T-240/10 - Hungary v Commission - of December 13 2013.; ECLI:EU:T:2013:645

8. Case T-139/07 Pioneer Hi-Bred International v. Commission; ECLI:EU:T:2009:307

9. Case T-405/10: Judgment of the General Court of 16 September 2014 - Justice \& Environment v Commission (Harmonization of legislation - Intentional introduction of GMOs into the environment - Procedure for marketing authorization - Internal review request Annulment Challenged or Relevant Decisions - Termination of Disputes - Suspension of Proceedings); ECLI: EU: T: 2014: 821

10. Joint cases T-366/03 and T-235/04 Land Oberösterreich and Republic of Austria v. Commission of the European Communities [2005] ECR II-04005; ECLI:EU:T:2005:347

11. Case C-111/16 the request for a preliminary ruling - Agriculture - Genetically modified food and feed - Emergency measures - National measure prohibiting the cultivation of genetically modified maize MON 810 - Retention or extension measures - Regulation (EC) No. 1829/2003 - Article 34 - Regulation (EC) No. 178/2002 - Articles 53 and 54 - Conditions of application - The precautionary principle

12. Case C-528/16 of 25 July 2018 refers to the following: Request for a preliminary ruling - Intentional introduction of genetically modified organisms into the environment - Mu- 
tagenesis - Directive 2001/18/EC - Articles 2 and 3 - Annexes IA and IB - Genetically Modified Organisms - Methods of genetic modification which are conventionally used and considered safe - New techniques/methods of mutagenesis - Risks for human health and the environment - Margin of Member States' judgment when transposing the Directive - Directive 2002/53/EC - Common catalogue of varieties of agricultural plant species - Herbicide resistant herbal varieties - Article 4 - Acceptability for a common catalogue of genetically modified grains obtained by mutagenesis - Requirement in the field of human and environmental health protection - Exemption; ECLI:EU:C:2018:583

\section{WEBSITE REFERENCES}

1. [https://ec.europa.eu/info/policies/consumers/consumer-protection/consumer-strategy_hr] Accessed 02.02.2019

2. Vuk, M., Eugenika i moderna medicina, Spectrum, Bioetički blok; available at: [file:///C:/Users/Mirela\%20Mezak\%20Matijev/Downloads/Martina_Vuk_Eugenika_i_moderna_medicina\%20(1).pdf] Accessed 12.5.2019 